\title{
A Study on the Effectiveness of Written Feedback in Writing Tasks among Upper Secondary School Pupils
}

\author{
Christina Plaindaren 1,2, Parilah Mohd Shah² \\ ${ }^{1}$ SMK Abdul Rahman Talib, Kuantan, Malaysia \\ ${ }^{2}$ Universiti Kebangsaan Malaysia, Bandar Baru Bangi, Selangor, Malaysia \\ Email:pchrisj@yahoo.com,drparila@gmail.com
}

How to cite this paper: Plaindaren, C., \& Shah, P. M. (2019). A Study on the Effectiveness of Written Feedback in Writing Tasks among Upper Secondary School Pupils. Creative Education, 10, 3491-3508. https://doi.org/10.4236/ce.2019.1013269

Received: December 5, 2019

Accepted: December 28, 2019

Published: December 31, 2019

Copyright () 2019 by author(s) and Scientific Research Publishing Inc. This work is licensed under the Creative Commons Attribution International License (CC BY 4.0).

http://creativecommons.org/licenses/by/4.0/

\section{c) (i) Open Access}

\begin{abstract}
This research is a study on the feedback received among upper secondary school pupils on their writing tasks in school. As it is known, English is the second language taught in schools in Malaysia. Among the four skills taught in the English classroom, the writing skill is said to be one of the most difficult skills to be acquired. There are many methods and strategies that have been carried out by teachers and pupils to make acquiring this skill easy. Giving feedback to pupils' writing task has been one of the methods used to teach writing effectively. However, this skill continues to be the most difficult and the most time consuming skill to be taught and learned. Therefore, a study was carried out among 30 pupils of SMK Abdul Rahman Talib to examine the types of feedback received by secondary school pupils and the perception of pupils towards the feedback they received. Questionnaires were distributed to pupils which consist of four sections. Respondents were required to answer all sections. The data was analysed using SPSS. Based on the data collected, the results clearly showed that the feedback received by pupils helped them improve their writing skills. Thus, this study has proven that giving feedback in writing tasks is essential for pupils and it can make the teaching and learning of the writing skill easier to be carried out. Therefore, teachers have to practice giving written feedback in pupils' writing tasks.
\end{abstract}

\section{Keywords}

Writing Skills, Feedback, Types of Feedback, Upper Secondary

\section{Introduction}

Language is essential in a community as it is how interaction is carried out be- 
tween people. It is the most common feature in a community. Most countries have a particular language which is dominant. However, for multiracial countries like Malaysia, there are a variety of languages which are used in people's daily communication. Teaching English involves teaching the four main skills, namely listening, speaking, reading and writing.

As it is stated above, writing is one of the language skills in learning the English language. According to Floyd et al. (2007), writing is an essential part of language learning and it is the process of encoding the words. In other words, this means how people use words in writing in order to communicate or to put into writing what they think or what they intend to say. There are many ways how people use writing to do these things such as writing journals, diaries, memo, emails, letters or even poems. It is up to the writers themselves on which way they want to express their ideas and feelings.

It is important to teach all four skills in Malaysian schools as pupils in Malaysian schools sit for numerous major examinations at different levels which tests all four skills. There are at least three major examinations in Malaysia that are the Ujian Penilaian Sekolah Rendah (UPSR) at the primary level. Then, there is the Penilaian Tingkatan Tiga (PT3) and the Sijil Pelajaran Malaysia (SPM) which are taken by pupils at the secondary school level. In all these major examinations, the writing skill is the main skill which is assessed. It is given utmost importance in all papers as it carries the most marks. For example, in Sijil Pelajaran Malaysia, there are two papers in which pupils are assessed. Paper one tests solely on pupils' writing skills where pupils are required to write two essays which are about 250 to 350 words. Paper one consists of 80 marks of the whole paper which is 155 marks. This means more than $50 \%$ of the total marks come from writing skills. Besides, in paper two, pupils will also have to write a summary based on a reading comprehension passage given and a short essay based on the novel that they have studied. This proves that writing skills are given the utmost importance in the education system in Malaysia.

Thus, a huge focus needs to be given on teaching the writing skill to the pupils. However, many have found this a strenuous task for both pupils and teachers. According to Yunus et al. (2017), writing skill is the most difficult skill to be mastered by Malaysian pupils compared to any other skills. Akinwamide (2012) states that this skill is the most difficult task to be accomplished in the classroom. Writing a good piece of essay in English is difficult for pupils despite learning the language for six years in the primary school and another five years in the secondary school. This is so because writing requires cognitive and linguistic strategies that pupils are not aware of (Maghsoudi \& Haririan, 2013). According to Yunus and Chien (2016), for a writer to be good in producing a good piece of writing he or she must have comprehensive knowledge of grammar, a wide range of vocabulary, has mastered the writing mechanics and has a varied style in writing.

Written feedback is essential in writing as it helps pupils identify their mis- 
takes and do editing to their writing. But, there are no proper guidelines as to how and what to give in a feedback for pupils' writing task. According to a study carried out by Raihany (2014), it is found that there are a few common problems with teachers' written feedback, that is, the feedback focuses mainly on grammar, feedback given is not clear and there are too many negative feedback given. This shows that teachers do not have proper guidelines to give feedback which makes pupils have difficulty in correcting their written tasks.

In most writing classrooms, pupils are only given feedback in the final draft which doesn't carry any purpose as the final product is completed. According to Al-Bashir et al. (2016), feedback plays the role of helping pupils to improve their written task from what they have written to what they desire to write. It is a whole process of writing where pupils use the feedback given and do some editing to their written tasks making it a better piece of writing. Feedback plays an important role as it is the only guide a pupil gets in improving their writing. There are different types of feedback that can be given such as general feedback, specific feedback, positive feedback or direct feedback. Giving just any kind of feedback is not an effective way of giving feedback. Giving feedback based on guidelines is important as the teacher will know what to write in the feedback based on what the pupil has written in their writing task. It will also help pupils to understand what their teacher has given them as feedback. This will help pupils make the necessary corrections. When there is a proper guideline then the feedback will be effective.

Feedback also needs to be given in the pupils draft and not in their final product as once the final product is completed, the function of a feedback will not be effective. Feedback needs to be given in the draft as it will help pupils improve their writing where they can improve their writing and send in more drafts before the final product is done. The final product is usually the written piece that has gone through several processes of correction. According to Fisher and Frey (2012), one of the problems faced in giving written feedback is, the teacher fails to identify the pattern in which the pupil makes a mistake. Teachers take time to look for mistakes pupils make and try hard to correct them. However, if a pattern can be identified then the mistakes will not be repeated.

Therefore, a research was carried out to find out the types of feedback pupils get and how it effects upper secondary school's pupils' writing skills. By getting the results to these questions, teachers can give proper feedback in order to improve pupils' writing skills. This will enable the pupils to improve their writing skills as they have corrected and edited their writing multiple times.

\section{Literature Review}

\subsection{Written Feedback}

Written feedback is often given in a process based approach. Kagimoto and Rodgers (2007), states that there are various types of feedback given in a writing task. They state that there are six types of corrective feedback which are explicit 
correction, recasts, clarification request, metalinguistic feedback, elicitation and repetition.

Larsen-Freeman (2003) defines feedback as information regarding evaluation of the learners' performance which is given to the learner. Although there are a myriad of ways to give feedback, teachers should make sure that the feedback given is effective as effective feedback helps pupils improve their writing whereas feedback which is not effective will not help pupils achieve anything. Effective feedback must use appropriate techniques and must be focused besides being supportive and non-judgemental. Giving feedback is not easy as it requires a lot of reading by the teacher and the teacher needs to thoroughly read the essay before giving feedback. Feedback which only consists of negative feedback may only demotivate pupils to write. It is the teacher's role to motivate pupils to write.

Written feedback in a writing task is important as pupils need to know the progress they are making in their writing task. Feedback can be done in many ways such as verbally and written feedback. In this study, focus will be given to written feedback. According to Wiggins (2012), feedback will provide the learner with a better understanding on what to do in order to make their writing skills proficient. When a learner is guided on the mistakes he or she makes, it will be easier for the learner to correct their mistakes and edit their writing. A majority of teachers use the product based approach in teaching writing as it is easier and not time consuming. Using this approach, much focus is given to the product itself rather than the process of writing. Thus, pupils cannot get to know what the mistakes they make in their writing are.

Glenn and Goldthwaite (2014), state that written feedback in a pupil's written work shows that the teacher has read the pupils work thoroughly. In order to give a written feedback, teachers will have to go through every sentence and every word that the pupils write. Thus, when looking at the feedback given, pupils will be rest assured that the teacher has gone through their piece of writing thoroughly. This gives the pupils a sense of pride that the teacher has read their writing. In this case giving positive feedback will be essential although there are a lot of errors as pupils will not be discouraged to write when they see a positive feedback. They will want to correct and edit their writing and let their teacher give more feedback on their writing. Bitchener (2008), states that correcting an error in a pupil's writing task is useful for a pupil as it not only improves pupils' language accuracy in the short term but also in the long term. Pupils will tend to remember their mistakes made when they are corrected in a written form rather than just verbally letting the pupils know of their mistakes. The pupils might repeat the mistake once more or twice, but eventually they will remember that particular mistake and remember not to repeat the mistake anymore.

According to Ferris (2003), besides error feedback by teachers, notes and end comments are also helpful for pupils in their writing. As stated earlier, giving positive feedback besides the negative feedback is important to encourage pupils to write. If pupils only see negative feedback every time they send in their essay, 
they will tend to give up on trying to write. Ferris further states that grammar corrections are the most successful kind of feedback. Most teachers are keen to correct the grammar of their pupils as that is the first thing that catches the teacher's eyes. Not only that, the curricular in most countries gives much emphasis on the grammar rather than the content. Teachers feel that it is wrong if they do not correct their pupils' errors and if they continue to allow their pupils to make grammatical errors. Thus, teachers must have a guideline as to how to assess pupils' essays and on what aspects or elements should feedback be given. Based on a study carried out in Pakistan by Gul and Rodrigues (2012), on the feedback given by an ELT teacher, it shows that the focus of the feedback given by the teacher was on grammar and mechanics. Although the teacher thought that she focused on the type of writing, but the results of the study showed otherwise.

Corcoran, Halverson and Schindler (2014), state that pupils get to know about their weaknesses and strengths through written feedback. This is true, as when pupils are given feedback on their essays, they tend to identify their good points and their weak points. This will enable the students to rectify the mistakes they make and not to continue making the same mistakes. Iqbal, Gul, Lakhani and Rizvi (2014), also agree that feedback is done to identify pupils' strength and weaknesses.

Based on a study carried out by Khalid (2011) in Indonesia, it was proven that feedback from the teacher and peers made pupils write better. He further stated that feedback from the teacher is mostly used in elementary and junior high schools whereas peer feedback is widely used in tertiary level of education. In the tertiary level of education, peer feedback can be carried out as pupils would have already been well versed with the techniques of writing and grammar.

According to a study by Chandler (2003), pupils feel that when their teacher corrects their essays and gives feedback by describing the errors that pupils made, makes pupils learn better and never to repeat the mistakes again. The study also showed that pupils' grades increased by $20 \%$ as a result to the feedback given by their teachers. This shows that giving feedback is important as pupils can identify their mistakes and are able to make corrections before coming up with the final product. Thus, feedback by teachers is essential in acquiring the writing skill.

Kingston and Nash (2011), states that feedback can be made as a formative assessment to help pupils in their learning. It will also help pupils to achieve their goals in writing compared to the level of understanding they first started with. By giving feedback, pupils will know what mistakes they have done and what they can correct. As when they first start writing, some pupils might make a lot of grammatical mistakes or organization mistakes. As the teacher corrects their writing and gives them feedback, they will tend to learn something while editing their writing.

Written feedback can be given in many ways. Many times there is no proper guideline for the teacher to give a feedback. Most teachers usually use the marking 
scheme for their writing task to give their feedback to pupils. Feedback can focus on different problems such as the content, word choice, spelling, punctuation and language. Different groups of pupils might require different types of feedback. Thus, the teacher might need to spend more time to read the pupils' writing and give direct feedback to pupils in order for the pupils to correct their mistakes.

\subsection{Teaching Writing Skills to Upper Secondary School Pupils}

Writing skill is essential as people write everyday even in the simplest form. Thus, teaching writing in schools is important. In schools, there are different types of writing that are taught. In Form 3, pupils write recounts, emails, and notes. Whereas in Form 5 pupils write speeches, articles, letters and reports, besides, narrative, argumentative, descriptive and factual essay. In order to write all these different types of essays, pupils need to master the writing skill. They need to think, generate ideas, plan their tasks, edit their writing and produce a piece of writing. Thus, mastering the writing skills in school is essential for pupils.

According to Kellogg (2008), writing skill is essential to be taught in schools as it helps in the improvement of pupils' grammatical structure, pupils' vocabulary and it also assists in other skills in English that is listening, speaking and reading. All this happens in the process of writing when the teacher gives feedback on a written task of pupils. Pupils tend to correct their mistakes and edit their tasks according to the feedback given by the teacher. When they do this they tend to improve in their writing as the feedback works as a guideline for pupils to learn and correct their mistakes.

According to Geiser and Studly (2001), the learning process is a success when one can write in a productive way. This shows that writing skill is not just learning to write but learning to write in a productive way. People write every day in their life. Thus, this skill is essential.

Writing skill is stated as being a cognitive skill as it involves language competency, recalling ability and thinking ability. Kellogg, Olive and Pilot (2001) state that writing needs information from a long term memory. Whatever a pupil learns in acquiring the skill goes a long way in the learning process. This is a cognitive skill. In order to produce a productive piece of writing we need to understand the things that we write.

According to Wren and Marten (2006) in order to write, pupils have to construct sentences without making grammatical errors and also use the correct terminology and spelling. That is the reason why writing skill is considered one of the most difficult skill to acquire as it involves many processes when writing. Pupils not only must care for the content when they write but they also need to make sure their mechanics are correct while paying attention to the organization, spelling, tone and style. Lim and Wong (2015), state that vocabulary, correct grammar, generating and developing ideas are some of the things that pupils of second language struggle with. They have problem thinking of ideas in the English language as they have limited vocabulary. They cannot develop the ideas 
and they cannot think creatively. This will not be able to make them write well as it stands as a hindrance to produce a good piece of writing. Thus, teachers need to come up with effective strategies to teach writing using different strategies as different pupils have different abilities to write. So, one strategy cannot be used to teach different level of pupils.

Thus, teaching writing skills in secondary schools in Malaysia is essential as pupils are required to write in their examination. A big part of the examination tests pupils on writing skills. To teach writing skills, a proper method is vital. One of the methods that can help to pupils to improve in their writing is by getting written feedback from their teachers for their written tasks. Thus, this study aims to investigate the effectiveness of written feedback on pupils' writing skills.

\section{Methods}

\subsection{Introduction}

Methodology is the ways that are used to conduct the research. This chapter discusses the steps involved in conducting the research. Further discussions will be carried out on the population and samples, the research instruments, limitation of the instruments and the process of analysing data.

\subsection{Research Design}

This study is a quantitative research. This research explains the perspective of students' on feedback that they receive for their writing tasks.

This study is a questionnaire and the questionnaires were adapted from a previous study (Lee, 2011) and (Saidon Said, Tuan Soh, \& Husnin, 2018). It was then modified to suit this study. The questionnaires are divided into four parts. The first part is the frequency of feedback received. The second part is the frequency of comments received according to language aspects. The third part of the questionnaire is the types of comments received and the last part is the students' perception on the written feedback received. In this study, for the written feedback, focus is given on the commentaries and rubrics. Commentaries help pupils to understand what the readers' confusion is when reading the pupils' writing. Rubric is grading according to a particular band or criteria. This study has explained the feedback received by pupils in the upper secondary school at SMK Abdul Rahman Talib, Kuantan, Pahang.

\subsection{Site}

This study was carried out in a secondary school in the district of Kuantan, Pahang. Kuantan is the capital city of Pahang and the biggest district in Pahang. The school is a government funded national secondary school and also a high achievement school (Sekolah Berprestasi Tinggi). The chosen school is the school where the researcher teaches that is SMK Abdul Rahman Talib. This school started its operations on $12^{\text {th }}$ January 1967 and was named after the $2^{\text {nd }}$ Minister of Education. In 1981, the school started two Rancangan Khas classes 
and continued to become a Sekolah Bestari in 1999. Now it has become a high achievement school after years of producing good results. Thus, the pupils who enrol in this school are the selected ones.

\subsection{Population}

Population is a group of people who are used in a research to gain answers and solutions. Dale (2006) states, readers must have a clear understanding of the study and the population must be specific. This study will be conducted among the upper secondary school pupils.

30 pupils of form four and five were selected as respondents. These pupils will be sitting for their SPM examinations this year and late next year. In this examination, English is one of the subjects that pupils must sit for. The pupils are aged between $16-17$ years. They are a mixture of male and female.

A few techniques can be followed to select samples from the population such as Simple Random Sampling, Stratified Sampling, Cluster Sampling and Systematic Sampling (Dale, 2006).

For this study, the simple random sampling technique was used to select the samples needed. Names of pupils were randomly selected for this purpose.

\subsection{Instrument}

The instruments used were a questionnaire survey. It was a self-administered questionnaire. The questionnaires were given to the respondents to be completed by the researcher. The instructions were read loud and clear by the researcher. The respondents were then given time to complete the questionnaires.

The questionnaires contained 4 sections. Section A was the frequency of feedback received by pupils. Section B was the frequency of comments received according to language aspects, section $\mathrm{C}$ was types of comments received and section $\mathrm{D}$ was pupils' perception of the written feedback.

\subsection{Data Collection Procedure}

A total of 30 pupils of form four and form five were chosen to be the respondents using the purposive sampling method. The study was carried out in three months. The pupils were given a topic to write on. After having a brainstorming session with pupils on the content points, they were asked to write the introduction paragraph first. The teacher then assessed the paragraph and gave feedback to pupils. The pupils then corrected their errors and edited their paragraphs and sent it again to their teacher. Once the paragraph was corrected, pupils then moved on to the next paragraph and the procedure was repeated. The essays was assessed according to the band in the SPM Paper 1 marking scheme.

\subsection{Data Analysis}

SPSS (Version 20 Software) was used to analyse the data. Respondents' answers were transferred to an Excel table to make it easier to transfer the data into SPSS. 
The data was based on dependent and independent variables.

\section{Results}

\subsection{Introduction}

This chapter discusses the results obtained from the data collected. The data was analysed using SPSS. There were four sections in the questionnaire. The results for all four sections will be discussed further in this chapter.

\subsection{Results}

There were a total of 30 respondents who were selected randomly as to when they were able to answer the questionnaires at the same time. Out of the 30 respondents 20 were male respondents and 10 were female respondents. All the respondents were from the age group between 16 to 17 years old. There were 18 respondents who were 16 years of age and 12 respondents who were 17 years of age. They formed four and form five pupils of different racial backgrounds. Respondents from different racial backgrounds were chosen to avoid racial bias.

There are four parts to the findings that are the frequency of feedback received by pupils, the frequency of comments received by pupils, types of comments received by pupils and pupils' perception of written feedback received.

Table 1 shows the frequency of feedback received by pupils in their final drafts only. As indicated in Table 1, 30\% of the pupils said that they received feedback from teachers only for their final drafts. That shows they have only sent in their final drafts or other drafts sent were not given feedback on. Another $70 \%$ of pupils said that they did not receive feedback for their final drafts only. This may be due to them sending in a few drafts before submitting their final product. This also shows that they have corrected their writing before sending in their final drafts.

Table 2 shows the frequency of feedback received by pupils in their first and

Table 1. Frequency of feedback on writing.

\begin{tabular}{cccccc}
\hline \multicolumn{6}{c}{ FINAL DRAFT } \\
\hline & Frequency & Percent & Valid Percent & Cumulative Percent \\
\hline \multirow{3}{*}{ Valid } & YES & 9 & 30.0 & 30.0 & 30.0 \\
& NO & 21 & 70.0 & 70.0 & 100.0 \\
& Total & 30 & 100.0 & 100.0 & \\
\hline
\end{tabular}

Table 2. Frequency of feedback on writing.

\begin{tabular}{lccccc}
\hline \multicolumn{5}{c}{ FIRST AND FINAL DRAFT } \\
\hline \multirow{4}{*}{ Valid } & Frequency & Percent & Valid Percent & Cumulative Percent \\
\hline & YES & 3 & 10.0 & 10.0 & 10.0 \\
& NO & 27 & 90.0 & 90.0 & 100.0 \\
\hline
\end{tabular}


final drafts of their written tasks. It is seen that $10 \%$ of the pupils received feedback for their first and final drafts. This shows that pupils have sent in at least two written tasks, one being the first draft and another being the final product after receiving feedback for their first draft. Another $90 \%$ of the pupils did not receive feedback for their first and final drafts. This may be due to the pupils who did not send in their drafts or they might have sent in their drafts but did not receive feedback on their drafts.

Table 3 shows the frequency of feedback received by pupils for multiple drafts and final drafts. $60 \%$ of the pupils received feedback for multiple drafts and their final drafts. This shows that pupils have done multiple drafts of their written tasks and have received feedback for their tasks. Pupils have corrected their mistakes based on feedback received and have sent in another draft before the final draft is ready. Another $40 \%$ of pupils did not receive feedback for their multiple drafts and final drafts. This shows that pupils did not do multiple drafts and maybe this is due to pupils not getting feedback for their written tasks.

Table 4 and Table 5 show the percentage and the frequencies of comments received according to language aspects. Grammar is an aspect that is most commented on with $80 \%$ of pupils stating that they always receive feedback on grammar $(\mathrm{M}=3.80, \mathrm{SD}=0.41)$. This shows that the most important element is grammar and it is still important in language learning.

Meanwhile, $76.6 \%$ of the respondents have stated that they always receive comments on mechanics $(\mathrm{M}=3.77, \mathrm{SD}=0.43)$ and $23.3 \%$ of respondents said that they often receive feedback on mechanics. This shows that as much as grammar is important, mechanics of writing such as spelling, punctuation and capitalization are also important.

Table 3. Frequency of feedback on writing.

\begin{tabular}{cccccc}
\hline \multicolumn{5}{c}{ MULTIPLE DRAFTS AND FINAL DRAFTS } \\
\hline \multirow{4}{*}{ Valid } & Frequency & Percent & Valid Percent & Cumulative Percent \\
\hline & YES & 18 & 60.0 & 60.0 & 60.0 \\
& NO & 12 & 40.0 & 40.0 & 100.0 \\
& Total & 30 & 100.0 & 100.0 & \\
\hline
\end{tabular}

Table 4. Percentage of comments received.

\begin{tabular}{ccccc}
\hline \multirow{2}{*}{ Comments Received } & \multicolumn{4}{c}{ Percentage (\%) } \\
\cline { 2 - 5 } & Never & Occasionally & Often & Always \\
\hline GRAMMAR & - & - & 20.0 & 80.0 \\
MECHANICS & - & - & 23.3 & 76.7 \\
WORD CHOICE & 63.3 & 36.7 & - & - \\
CONTENT & 13.3 & 56.7 & 30.0 & - \\
ORGANIZATION & - & 36.7 & 50.0 & 13.3 \\
PARAGRAPH CONSTRUCTION & - & 53.3 & 40.0 & 6.7 \\
\hline
\end{tabular}


Table 5. Frequency of comments received according to language aspects.

\begin{tabular}{cccccc}
\hline \multicolumn{6}{c}{ Descriptive Statistics } \\
& N & Minimum & Maximum & Mean & Std. Deviation \\
\hline GRAMMAR & 30 & 3.00 & 4.00 & 3.8000 & 0.40684 \\
MECHANICS & 30 & 3.00 & 4.00 & 3.7667 & 0.43018 \\
WORDCHOICE & 30 & 1.00 & 2.00 & 1.3667 & 0.49013 \\
CONTENT & 30 & 1.00 & 3.00 & 2.1667 & 0.64772 \\
ORGANIZATION & 30 & 2.00 & 4.00 & 2.7667 & 0.67891 \\
PARAGRAPHCONSTRUCTION & 30 & 2.00 & 4.00 & 2.5333 & 0.62881 \\
Valid N (listwise) & 30 & & & & \\
\hline
\end{tabular}

$63.3 \%$ of respondents said that they never get feedback on word choice while, $36.7 \%$ of respondents said they got feedback on word choice occasionally $(\mathrm{M}=$ $1.37, \mathrm{SD}=0.49$ ). This shows only a small number of pupils get feedback on the words they choose to use.

For the aspect of content, $56.7 \%$ of the respondents said that they occasionally got feedback for their writing on that aspect, whereas, $13.3 \%$ of the respondents said they never receive feedback on content $(\mathrm{M}=2.17, \mathrm{SD}=0.65)$. Another $30 \%$ of respondents often receive feedback on content. This clearly shows that the grammar aspect is given more importance than the content of the written task itself.

$50 \%$ of respondents said that they often receive feedback on the organization of the writing, while $36.7 \%$ of respondents said they occasionally receive feedback on organization $(\mathrm{M}=2.77, \mathrm{SD}=0.68)$. Another $13.3 \%$ of the respondents said they always get feedback on the organization. This shows that organizing an essay is very important as it will clearly show the teacher what the writer is trying to convey.

For the aspect of paragraph construction, $53.3 \%$ of the respondents said that they occasionally receive feedback on this aspect whereas $40 \%$ of the respondents said they often receive feedback on this aspect $(\mathrm{M}=2.53, \mathrm{SD}=0.63) .6 .7 \%$ of the respondents said they always receive feedback on paragraph construction.

Table 6 and Table 7 show the percentage and the mean of types of comments received. For the aspect of general comments, $70 \%$ of the respondents said that they received general comments occasionally while $16.7 \%$ of the respondents said that they often received general comments $(\mathrm{M}=2.43, \mathrm{SD}=0.73)$. Another $13.3 \%$ of the respondents said that they always receive general comments. This shows that feedback received does not show pupils how to correct their errors.

For the aspect of detailed feedback, $53.3 \%$ of the respondents said that they often receive detailed feedback on their writing whereas, $30 \%$ of the respondents said that they occasionally received detailed comments $(\mathrm{M}=2.87, \mathrm{SD}=0.68)$. Another $16.7 \%$ of the respondents said that they always receive detailed feedback. 
Table 6. Percentage on types of comments received.

\begin{tabular}{ccccc}
\hline \multirow{2}{*}{ Types of Comments } & \multicolumn{4}{c}{ Percentage (\%) } \\
\cline { 2 - 5 } & Never & Occasionally & Often & Always \\
\hline GENERAL & - & 70.0 & 16.7 & 13.3 \\
DETAILED & - & 30.0 & 53.3 & 16.7 \\
POSITIVE & 10.0 & 70.0 & 20.0 & - \\
NEGATIVE & - & 13.3 & 70.0 & 16.7 \\
DIRECT & - & 70.0 & 16.7 & 13.3 \\
INDIRECT & 76.7 & 23.3 & - & - \\
\hline
\end{tabular}

Table 7. Types of comments received.

\begin{tabular}{cccccc}
\hline \multicolumn{5}{c}{ Descriptive Statistics } \\
\hline N & Minimum & Maximum & Mean & Std. Deviation \\
\hline GENERAL & 30 & 2.00 & 4.00 & 2.4333 & 0.72793 \\
DETAILED & 30 & 2.00 & 4.00 & 2.8667 & 0.68145 \\
POSITIVE & 30 & 1.00 & 3.00 & 2.1000 & 0.54772 \\
NEGATIVE & 30 & 2.00 & 4.00 & 3.0333 & 0.55605 \\
DIRECT & 30 & 2.00 & 4.00 & 2.4333 & 0.72793 \\
INDIRECT & 30 & 1.00 & 2.00 & 1.2333 & 0.43018 \\
Valid N (listwise) & 30 & & & & \\
\hline
\end{tabular}

For the aspect of positive feedback, $70 \%$ of the respondents said that they occasionally receive positive feedback while, $20 \%$ said that they often receive positive feedback $(\mathrm{M}=2.10, \mathrm{SD}=0.55)$. However, another $10 \%$ said that they never receive positive feedback for their writing task. This shows that feedback is mostly given only to highlight the errors that pupils have done.

For the aspect of negative feedback, however, there is a majority of respondents who said they receive negative feedback from their teachers. $70 \%$ of the respondents said they often receive negative responses while $16.7 \%$ said they always receive negative feedback from their teachers $(M=3.03, S D=0.56)$. Another $13.3 \%$ of the respondents said that they occasionally receive negative feedback from their teachers.

For the aspect of direct feedback, $70 \%$ of the respondents said they occasionally receive direct feedback from their teachers whereas $16.7 \%$ respondents said they often receive direct feedback from teachers $(\mathrm{M}=2.43, \mathrm{SD}=0.73)$. Another $13.3 \%$ of the respondents said that they always receive direct feedback.

Finally, for the aspect of indirect feedback, $76.7 \%$ of the respondents said they never receive indirect feedback from their teachers and $23.3 \%$ of the respondents occasionally receive indirect feedback from their teachers $(\mathrm{M}=1.23, \mathrm{SD}=0.43)$.

Table 8 and Table 9 show the percentage of pupils' perception towards feedback. For the aspect of motivating, $70 \%$ of the respondents said that the feedback 
they get is occasionally motivating. While $16.7 \%$ of respondents said they often get motivating feedback whereas, $13.3 \%$ of pupils said they always get motivating feedback $(\mathrm{M}=2.33, \mathrm{SD}=0.55)$.

Meanwhile, for the aspect of too general, 30\% of respondents said that they occasionally received feedback which was too general. Another $53.3 \%$ of respondents said that they often got feedback that was too general and $16.7 \%$ of the respondents said they always get feedback that was too general $(\mathrm{M}=2.7, \mathrm{SD}=$ $0.47)$.

For the aspect of whether the pupils enjoy the feedback, $70 \%$ of the respondents said that they enjoy the feedback that they get occasionally and another $20 \%$ of the respondents said that they enjoy getting feedback often while $10 \%$ of the respondents never enjoy the feedback that they get $(\mathrm{M}=2.17, \mathrm{SD}=0.64)$.

Whether the feedback helps to improve their writing, $70 \%$ of the respondents said that the feedback often helps them to improve their writing while $16.7 \%$ of the respondents said that the feedback they get helps to improve their writing and $13.3 \%$ of the respondents said the feedback they get occasionally helps them to improve their writing $(\mathrm{M}=3.0, \mathrm{SD}=0.37)$.

For the aspect of whether they feel good about getting the feedback, $70 \%$ of the respondents said that they occasionally feel good to receive feedback while, $16.7 \%$ often feel good about the feedback they receive and another $13.3 \%$ of the respondents always feel good about the feedback they receive $(\mathrm{M}=1.97, \mathrm{SD}=$ $0.41)$.

Table 8. Percentage of pupils' perception.

\begin{tabular}{ccccc}
\hline \multirow{2}{*}{ PUPILS' PERCEPTION } & \multicolumn{4}{c}{ Percentage (\%) } \\
\cline { 2 - 5 } & Never & Occasionally & Often & Always \\
\hline MOTIVATING & - & 70.0 & 16.7 & 13.3 \\
TOO GENERAL & - & 30.0 & 53.3 & 16.7 \\
ENJOY IT & 10.0 & 70.0 & 20.0 & - \\
HELPS TO IMPROVE & - & 13.3 & 70.0 & 16.7 \\
FEELS GOOD & - & 70.0 & 16.7 & 13.3 \\
\hline
\end{tabular}

Table 9. Pupils' perception.

\begin{tabular}{cccccc}
\hline \multicolumn{5}{c}{ Descriptive Statistics } \\
\hline & N & Minimum & Maximum & Mean & Std. Deviation \\
\hline MOTIVATING & 30 & 2.00 & 4.00 & 2.3333 & 0.54667 \\
TOOGENERAL & 30 & 2.00 & 3.00 & 2.7000 & 0.46609 \\
ENJOYIT & 30 & 1.00 & 4.00 & 2.1667 & 0.64772 \\
HELPSTOIMPROVE & 30 & 2.00 & 4.00 & 3.0000 & 0.37139 \\
FEELSGOOD & 30 & 1.00 & 3.00 & 1.9667 & 0.41384 \\
Valid N (listwise) & 30 & & & & \\
\hline
\end{tabular}




\section{Discussions and Recommendations}

The findings show the frequency of feedback received by pupils, the frequency of comments received by pupils, the types of comments received by pupils and the pupils' perception of the written feedback received.

For the number of feedback pupils received for their writing task, a majority of respondents said they received feedback for multiple drafts and their final drafts. This shows that teachers do take time to read pupils essays many times and thoroughly before giving feedback as they have given feedback for multiple drafts before the final draft was produced. This is stated in a study by Glenn and Goldthwaite (2014) which says that when a teacher gives feedback it shows that he or she has read the written task thoroughly. This would have helped pupils to identify their strengths and weaknesses in writing and also would have helped pupils improve in their writing. Feedback should be given in a multiple of drafts so that it will be effective feedback. When it is given in multiple drafts, pupils will learn to correct their errors themselves. They will also know in which aspect they are weak in and in which aspect their strength is in. This is also similar to the study by Kingston and Nash (2011) which states that feedback can be used as a formative assessment and it can help pupils achieve goals in writing. Feedback is given so that pupils can improve on their writing. If it is given only in the final draft then it will not serve its purpose as after the final draft, pupils will not correct their essays and they will also not send it into their teachers. Some pupils will not even read the comments given because as far as they are concerned that task is completed and nothing has to be done thereafter. Therefore, in order for feedback to be effective, pupils must write multiple times until their essays become a good piece of writing.

For the frequency of comments received, a majority of respondents said that they received feedback on grammatical errors and mechanics. This clearly shows that mastering the grammatical rules is an important task in learning writing skills. Pupils should be able to know when to use the correct tenses and also the verbs. The study also shows that very less focus has been given on the word choice and contents. This may be due to teachers following the Sijil Pelajaran Malaysia's marking scheme as a guideline as the marking scheme stresses on grammar and mechanics more than the content itself. If pupils have mastered the grammar than they will not have too many errors to be corrected. However, for pupils who have not mastered their grammar, they will have a lot of drafts to be prepared before their final product is completed. Content on the other hand is only a minimal part in the marking scheme. For organization and paragraph construction not much focus has been given.

In a piece of writing, grammar and mechanics is not the only important element. Importance should also be given to the content and organization of the essay. When the content is interesting, positive feedback should be given to the pupils. This will help to boost pupils' creativity in writing.

For the types of comments received, a big amount of respondents said that 
they received detailed feedbacks. This shows that teachers have taken the effort to read the whole essay before giving the feedback. A detailed feedback may include their strengths, weaknesses and how pupils can improve their writing. This will serve the purpose of giving a feedback. If only a general comment is given, pupils will not be able to correct their essays as they will not have any guide on how to do it. Thus, they will also not be able to improve in their writing. The purpose of a feedback is to help pupils improve on their writing. A detailed feedback will definitely help pupils to improve. A majority also said they received negative comments for their writing task. A negative comment will not be able to help pupils to improve in their writing as it will not motivate pupils to write rather it would discourage pupils to write. Pupils may lose interest if they keep receiving negative feedback. A feedback must not only speak on the weaknesses of pupils' writing but it must also highlight the strengths that the writing has. That will help pupils to have the interest to write. This will boost their motivation to learn the writing skill as this skill is already a difficult skill to be acquired.

On the perception that pupils have towards feedback, a majority of them said that it helps to improve their writing. This shows that pupils do improve their writing through the feedback they get from teachers. This is similar to the findings of Wiggins (2012), where it is stated that by getting feedback, learners can make their writing become more proficient as they have better understanding on what their mistakes are. This kind of feedback must include positive and negative feedback. The pupils' weaknesses should be highlighted for the pupil to improve and at the same time the strengths should also be commented on as an inspiration for pupils to do better in acquiring the writing skill. The feedback should also be a detailed and direct feedback. Every mistake of the pupils must be identified and every strength of the writing must be highlighted. When the feedback is detailed, it will help pupils to learn where they can improve and where they need to be corrected. The feedback also needs to be direct in order for the pupil to understand the mistakes they made better. If the pupils cannot understand what the feedback is about they will not be able to make corrections or improve on their writing. There were also very few pupils who said that it made them feel good to receive feedback. This shows that pupils do not like to receive feedback. This can be due to the type of feedback received. If pupils keep on receiving negative feedbacks they would lose the interest to write. They may not even read the comments given by the teacher. By giving positive feedback, the pupils should feel that their piece of writing is appreciated. They will also make the effort to read all the comments given.

\section{Recommendations}

As the study shows, feedback plays a very important role in teaching writing. Through feedback, pupils can correct their errors made in their written task and also improve their writing skills. 
However, giving feedback and writing multiple drafts before submitting the final product is time consuming. As mentioned earlier in the introduction, there are many aspects to be covered in teaching English in Malaysian schools. Besides, time is also an issue as there is very limited time allocated in teaching English in the classroom as a subject.

Thus, teachers can opt to use technology in teaching writing. Since technology is the current trend for pupils and not only that, a majority of households in Malaysia have access to technology in their homes, teaching and learning can be carried out using technology. This will make the task easier as pupils can complete their time out of the classroom, wherever they are. They will also be able to complete their tasks easily as they can do it using their mobile phones. As many pupils use a smartphone these days, completing a task out of classroom will not be a problem. These will solve many problems arising on teaching the writing skills. Many different platforms can be used to carry out writing activities such as Telegram, Facebook, Whatsapp and also Goggle Classroom. All these can help make teaching writing not only easier but also more interesting.

Besides, a further study can also be carried out using a larger population and more samples. The samples for this study were a small number and only based on one school. Thus, this study can be carried out in other secondary schools in the state or country.

\section{Conclusion}

Based on the findings, it can be concluded that there are teachers in Malaysian schools who practice giving feedback to their pupils in their writing tasks. However, how the process of giving feedback is carried out varies among teachers. There must be a standardized guideline for teachers to give feedback to pupils. This will help teachers to give feedback and also to help pupils to improve their writing. This study on pupils' perception will help teachers to see what pupils want as feedback and how they want it. This study has proven that feedback is necessary in order for pupils to improve their writing skills. However, more studies should be done as to how the process of giving feedback should be carried out. There must be a study on how the guidelines should be done to have effective feedback.

\section{Conflicts of Interest}

The authors declare no conflicts of interest regarding the publication of this paper.

\section{References}

Akinwamide, T. K. (2012). The Influence of Process Approach on English as Second Language Pupils' Performance in Essay Writing. English Language Teaching, 5, 16-29. https://doi.org/10.5539/elt.v5n3p16

Al-Bashir, M., Kabir, R., \& Rahman, I. (2016). The Value and Effectiveness of Feedback in Improving Students' Learning and Professionalizing Teaching in Higher Education. 
Journal of Education and Practice, 7, 38-41.

Bitchener, J. (2008). Evidence in Support of Written Corrective Feedback. Journal of Second Language Writing, 17, 102-118. https://doi.org/10.1016/j.jslw.2007.11.004

Chandler, J. (2003). The Efficacy of Various Kinds of Error Feedback for Improvement in the Accuracy and Fluency of L2 Student Writing. Journal of Second Language Writing, 12, 267-296. https://doi.org/10.1016/S1060-3743(03)00038-9

Corcoran, J., Halverson, A. L., \& Schindler, N. (2014). A Formative Midterm Test Increases Accuracy of Identifying Students at Risk of Failing a Third Year Surgery Clerkship. The American Journal of Surgery, 207, 260-262.

https://doi.org/10.1016/j.amjsurg.2013.10.009

Dale, D. (2006). Population Sampling Methods for Research Studies: Definitions and Uses.

http://voices.yahoo.com/population-sampling-methods-research-studies-definitions-3 2308.html?cat $=4$

Ferris, D. R. (2003). Response to Student Writing: Implications for Second Language Students. Mahwah, NJ: Lawrence Erlbaum Associates.

https://doi.org/10.4324/9781410607201

Fisher, D., \& Frey, N. (2012). Making Time for Feedback. Education Leadership, 70, 47-46.

Floyd, R. G., Keith, T. Z., Taub, G. E., \& McGrew, K. S. (2007). Cattell-Horn-Carroll Cognitive Abilities and Their Effects on Reading Decoding Skills: G Has Indirect Effects, More Specific Abilities Have Direct Effects. School Psychology Quarterly, 22, 200-233. https://doi.org/10.1037/1045-3830.22.2.200

Geiser, S., \& Studley, R. (2001). UC and the SAT: Predictive Validity and Differential Impact of the SAT and SAT II at the University of California. Educational Assessment, 8, 1-26. https://doi.org/10.1207/S15326977EA0801_01

Glenn. C., \& Goldthwaite, M. A. (2014). The St. Martin's Guide to Teaching Writing (7th ed.). Boston, MA: Bedford/St. Martin's.

Gul, M., \& Rodrigues, S. (2012). Unveiling The Focus of a Teacher's Written Feedback on Students' Composition Writing in Pakistan. International Research Journal, 1, 59-66.

Iqbal, S., Gul, R., Lakhani, A., \& Rizvi, F. N. (2014). Teachers' Accounts of Their Perceptions and Practices of Providing Written Feedback to Nursing Students on Their Assignments. International Journal of Higher Education, 3, 70-80.

https://doi.org/10.5430/ijhe.v3n3p70

Kagimoto, E., \& Rodgers, M. P. H. (2007). Students' Perception of Corrective Feedback. JALT, Conference Proceeding. In K. Bradord Watts, T. Muller, \& M. Swanson (Eds.), JALT 2007 Conference Proceedings (pp. 868-879). Tokyo: JAL.

Kellogg, R. T. (2008). Training Writing Skills: A Cognitive Development Perspective. Journal of Writing Research, 1, 1-26. https://doi.org/10.17239/jowr-2008.01.01.1

Kellogg, R. T., Olive, T., \& Pilot, A. (2001). Verbal, Visual and Spatial Working Memory in Written Language Production. ACTA Psychological, 124, 382-397. https://doi.org/10.1016/j.actpsy.2006.02.005

Khalid, M. (2011). English Writing Learning Technique. Majalah Ilmiah Ukhuwah, 6, $1-8$.

Kingston, N., \& Nash, B. (2011). Formative Assessment: A Meta-Analysis and Call for Research. Educational Measurement: Issues and Practice, 30, 28-37.

https://doi.org/10.1111/j.1745-3992.2011.00220.x

Larsen-Freeman, D. (2003). Teaching Language: From Grammar to Grammaring. Bos- 
ton, MA: Heinle \& Heinle Publishers.

Lee, I. (2011). Working Smarter, Not Working Harder: Revisiting Teacher Feedback in the L2 Writing Classroom. Canadian Modern Language Review, 67, 377-399. https://doi.org/10.3138/cmlr.67.3.377

Lim, S. P., \& Wong, M. M. (2015). Selfie: Engaging Life Experiences into Writing. Malaysian Journal of Distance Education, 17, 51-66.

Maghsoudi, M., \& Haririan, J. (2013). The Impact of Brainstorming Strategies Iranian EFL Learners Writing Skill Regarding Their Social Class Status. Journal of Language and Linguistics, 1, 60-67. https://doi.org/10.11648/j.ijll.s.20130101.20

Raihany, A. (2014). The Importance of Teacher's Written Feedback on the Students' Writing in Teaching Learning Process. Okara: Jurnal Bahasa dan Sastra, 8, 91-106.

Saidon, M. A., Mohd Said, N. E., Tuan Soh, T. M., \& Husnin, H. (2018). ESL Students' Perception of Teacher's Written Feedback Practice in Malaysian Classrooms. Creative Education, 9, 2300-2310. https://doi.org/10.4236/ce.2018.914170

Wiggins, G. (2012). Seven Keys to Effective Feedback. Educational Leadership, 70, 10-16.

Wren, P. C., \& Marten, H. (2006). High School English Grammar and Composition. New Delhi: S. Chand and Company Limited.

Yunus, M. M. et al. (2017). ESL Learner's Acceptance towards the Use of Technology in Enhancing Writing Skills. Journal of Advance Research in Dynamical \& Control Systems, 10, 02-Special Issue.

Yunus, M. M., \& Chien, C. H. (2016). The Use of Mind Mapping Strategy in Malaysian University English Test (MUET) Writing. Creative Education, 7, 619-626.

https://doi.org/10.4236/ce.2016.74064 